\title{
Performance of cover crops under two irrigation regimes in the Coastal Tablelands region of Brazil ${ }^{1}$
}

\author{
Lucas Rodrigues Nicole ${ }^{2 *}$, Dione Pereira Cardoso ${ }^{3}$, Fábio Ribeiro Pires ${ }^{2}$, Robson Bonomo ${ }^{2}$, \\ Benedicto Barbosa Netto ${ }^{2}$, Alessandra Ferreira Belo ${ }^{2}$
}

10.1590/0034-737X202168040007

\begin{abstract}
There is currently a lack of information regarding the performance of cover crops grown in the Coastal Tablelands region in the North of the Brazilian state of Espírito Santo, where zero tillage is increasingly being adopted. The objective of this study was to evaluate the agronomic performance of six cover crops (ruzi grass, jack bean, and the millets ADR 300, ADR 500, ADRf 6010, and BRS 1501) under two irrigation regimes. A field experiment setup was based on randomized blocks with split plots and four repetitions. Shoot dry matter content, plant height, leaf area, chlorophyll fluorescence, and root growth of the cover crops were evaluated. The irrigation regime influences the agronomic performance of most of the cover crops, with the exception of jack bean and ADRf 6010 millet, which were tolerant to water deficiency, based on our evaluations of the variables shoot dry matter, plant height, and leaf area. In terms of biomass production, ADRf 6010 millet is the most suitable crop for use in conservation systems under conditions of water stress in this region.
\end{abstract}

Keywords: millet; jack bean; ruzi grass; irrigation management.

\section{INTRODUCTION}

A conventional tillage system can promote tropical soil deterioration, due to the aggregate breakup as well as compaction and decomposition of the organic matter in the soil. A lack of cover crops increases soil exposure to inclement weather, facilitating water erosion, especially when conservation practices are not utilized.

Studies carried out in the Cerrado region of Brazil and in different soils and climates conditions using cover crops, mainly Fabaceae and Poaceae families, demonstrated a wide range of variability of results. These researches have evidenced positive effects provided by the different cover crops and their waste on the soil, interfering in the physical and chemical soil attributes as well as in agricultural yields of the crops subsequently cultivated (Boer et al., 2007; Gama-Rodrigues et al., 2007; Torres et al., 2008; Pedrotti et al., 2015; Silva et al., 2017).
For instance, Boer et al. (2007) verified that rotating cover crops, that had root systems reaching different soil levels, aids in nutrient recycling. Furthermore, this increases interaction with other organisms, decreases soil temperature, improves soil structure, and reduces erosion (Wutke et al., 2009).

Among the cover crops used, millet (Pennisetum glaucum L.) is very adaptable to regions with high temperatures, water deficits, and low fertility soils. This is a forage of significant biomass production, which makes it an excellent alternative for soil conservation management systems, such as the zero tillage system (Torres et al., 2008). The millet displays an even greater capacity for nutrient absorption and a vigorous root system. These characteristics make this particular species stand out from the other cover crops (Marcante et al., 2011).

\footnotetext{
Submitted on December $18^{\text {th }}, 2018$ and accepted on February $7^{\text {th }}, 2021$.

'Part of the Dissertation of Master's Degree of the first author

${ }^{2}$ Universidade Federal do Espírito Santo, São Mateus, Espírito Santo, Brazil. lukssnicoli@hotmail.com; pires.fr@gmail.com; robson.bonomo@gmail.com; benedictojr5@gmail.com; ferreiragro@yahoo.com.br

${ }^{3}$ Universidade Federal de Lavras, Lavras, Minas Gerais, Brazil. cardoso.dione@gmail.com

*Corresponding author: lukssnicoli@ hotmail.com
} 
The selection of plants that are cultivated in a specific area is very important for recovering and maintaining soil quality, because success in plant cultivation depends on the adaptations of crops to local soil and climatic conditions. Lack of water, for example, is a factor that limits plant production, and could even compromise productive potential. However, some species have proven to be more tolerant or adaptable to low water regimes. In this sense, irrigation management is a strategy that should be considered during plant development stages, especially given water shortages in recent years.

Studies of this nature are necessary in order to evaluate the options available regarding cover crops for possible future use of soil conservation systems in the Coastal Tablelands region of Brazil. Moreover, the cultivation of cover crops can significantly and positively influence the productivity of commercial crops planted in succession. In the state of Espírito Santo, particularly in its Northern region, where zero tillage crops have resurfaced in areas previously cultivated with perennial crops, studies regarding the development of cover crops is lacking and there is no information about the adaptability and performance of these plants. Therefore, the objective of this study was to evaluate the agronomic performance of cover plants using two irrigation regimes, with the goal future of adopting conservation systems in this region.

\section{MATERIAL AND METHODS}

This experiment was conducted in the Experimental Farm on the São Mateus campus of the Federal University of Espírito Santo, which is located in the municipality of São Mateus (1840'26'S; 3951'26”W; altitude: 39 m; average annual rainfall: $1240 \mathrm{~mm}$ ) in the Northern region of the Brazilian state of Espírito Santo. According to the Köppen classification, the climate of the region is $A w$ : tropical, with a dry season during the winter and rain during the summer (Alvares et al., 2013). The soil was classified as dystrophic yellow argisol (Santos et al., 2013) with loamy sandy (superficial layer) and sandy loam (subsurface layer) texture (Table 1) and flat terrain with an average declivity of $2 \%$.

The experiment was set up using a randomized block design in a $2 \times 6$ arrangement of split plots, with four repetitions. The treatments consisted of two irrigation regimes in the plots: irrigation regime $1(\mathrm{R} 1-76 \mathrm{~mm})$ and irrigation regime $2(\mathrm{R} 2-38 \mathrm{~mm})$, and six cover crops in the subplots: Pennisetum glaucum (L.) R. Brown (millets ADR 300, ADR 500, and BRS 1501 - straw production; ADRf 6010 - forage), Canavalia ensiformis (L.) DC. (jack bean $=\mathrm{JB}$ ), and Brachiaria ruziziensis Germain \& Evrard 'Comum' (ruzi grass = RG). Jack bean and ruzi grass, widely referenced in the literature, were used because they produce large amounts of biomass and are indicated for cultivation in the summer, in addition to being more accessible to rural producers in the region. The subplots were $5 \times 9 \mathrm{~m}$, composed of 16 lines $9 \mathrm{~m}$ in length, with a space of $0.30 \mathrm{~m}$ between the lines.

The total area was cultivated with black oats (Avena strigosa Schreb) for 70 days and desiccated four months before the beginning of the experiment. Then, soil samples were collected for chemical and physical characterization in the superficial (0.00-0.20 m) and subsurface (0.20-0.40 $\mathrm{m}$ ) layers of the soil (Table 1). Based on the results, liming and fertilization were recommended in order to meet the cultivation needs of the species. In line with the base saturation method (Quaggio, 1983), different amounts of dolomitic limestone were applied manually to each block, without incorporation, $50 \mathrm{~d}$ before planting.

The planting grooves were prepared and fertilized mechanically using a zero tillage seed drill with six lines, applying $500 \mathrm{~kg} \mathrm{ha}^{-1}$ of formulated 04-14-08 (15 g per meter). The seeding step was completed manually on 19 January 2016. The seeding density used was 100 seeds of ruzi grass per meter $\left(28 \mathrm{~kg} \mathrm{ha}^{-1}\right), 4$ seeds of jack bean per meter $\left(100 \mathrm{~kg} \mathrm{ha}^{-1}\right)$, and 70 seeds of each one of the millets per meter $\left(16 \mathrm{~kg} \mathrm{ha}^{-1}\right)$. There was no cover fertilization due to the objective of the study, which was to employ the species as cover crops.

A sprinkling irrigation system was used with a spacing of $12 \mathrm{~m}$ between the lines and the sprinklers. Due to significant droughts over the course of the study, which decreased the levels of reserved water, it was not possible to provide the irrigation at full depth corresponding to the estimated values given by the water balance method based on evapotranspiration. The year 2016 was atypical in terms of precipitation, with an annual value below 800 $\mathrm{mm}$. For this reason, irrigation depth was limited to $76 \mathrm{~mm}$ for R1 and $38 \mathrm{~mm}$ for R2 and water application intensity was $5.42 \mathrm{~mm} \mathrm{~h}^{-1}$. During the cultivation period, the water demand of the millet, the most water-demanding crop in this study, was $282.06 \mathrm{~mm}$. Of this total, the water deficit was $143.17 \mathrm{~mm}(50.76 \%)$ and $181.50 \mathrm{~mm}(64.35 \%)$, for R1 and R2, respectively. Irrigation stopped at 30 and $44 \mathrm{~d}$ after seeding (DAS) in the areas corresponding to R2 and $\mathrm{R} 1$, respectively.

Weed control consisted of weeding the experimental units and using the herbicide glyphosate $\left(2 \mathrm{~L} \mathrm{ha}^{-1}\right)$ in the rows of sprinklers and around the experimental area at 40 DAS. A sulfluramid formicide was also used at 40 DAS (bait applied in the intersections), as well as the insecticide deltamethrin $\left(200 \mathrm{~mL} \mathrm{ha}^{-1}\right)$ at 45 DAS (applied in all experimental units). The plants stopped being managed at 65 DAS.

Figure 1 shows the values for sunlight, air temperature, rainfall, irrigation, and air relative humidity (Inmet, 2016) recorded during the cultivation period of the cover crops, 
between 19 January 2016 and 24 March 2016. The total rainfall was $153.40 \mathrm{~mm}$ (Figure 1B).

The agronomic performance was evaluated by observing the shoot dry matter production, plant height, leaf area and root growth. Chlorophyll fluorescence was also evaluated.

The shoot dry matter (DM) production was determined at 52 DAS. Millet plants were collected from a $0.2 \times 0.3 \mathrm{~m}$ $\left(0.06 \mathrm{~m}^{2}\right)$ area and ruzi grass and jack bean plants from a $0.4 \times 0.3 \mathrm{~m}\left(0.12 \mathrm{~m}^{2}\right)$ area. The plants were weighed on a $0.01 \mathrm{~g}$ precision scale. Then, the samples were subjected to drying in a forced ventilation oven at $65^{\circ} \mathrm{C}$ until constant weight was obtained. After drying, each sample was weighed to determine the dry mass, estimating the production of phytomass $\left(\mathrm{kg} \mathrm{ha}^{-1}\right)$.

Plant height $(\mathrm{PH})$ was evaluated at $58 \mathrm{DAS}$ by a steel measuring tape. In total, 10 random plants were measured from the base to the apical meristem, within the useful area of each experimental unit.

Leaf area (LA) was determined at 60 DAS by using an automatic standing leaf area meter (Li-Cor ${ }^{\circledR}$ L1-3100). Plants were collected from a $0.2 \times 0.3 \mathrm{~m}\left(0.06 \mathrm{~m}^{2}\right)$ area and immediately taken to the laboratory for measurement.

The Multiplex ${ }^{\circledR}$ optical sensor (Force A, Orsay, France) generates fluorescence in the plant tissues using multiple excitation wavelengths (ultraviolet, blue, green and red) to estimate simultaneously the content of several compounds, including chlorophyll content, determined, in this case, from the chlorophyll $a$ fluorescence. The data collection occurred at 60 DAS in the central region of the intermediate leaves, on both the adaxial and abaxial sides of the same leaf in 5 plants per experimental unit.

Root growth was evaluated 65 DAS by gathering roots using a soil probe (probe style auger), with a gauge circumference of $1.75 \mathrm{~cm}$, at a depth of $10 \mathrm{~cm}$ and a distance of $5 \mathrm{~cm}$ from the base of the plants. This area was selected because it is a region with a high concentration of secondary roots. The collected soil volume was approximately $2.44 \mathrm{~cm}^{3}$. Subsequently, the roots were taken to the laboratory to be manually separated from the soil with tweezers. In addition, Safira ${ }^{\circledR}$ software, developed by Embrapa Instrumentação Agropecuária (Jorge \& Rodrigues, 2008), was used to analyse root images, with the purpose of determining total root length (TRL), average root length (ARL), total root volume (TRV), total root surface area (TRSA), and average root diameter (ARD). Root dry matter (RDM) production, by weight, was also measured, by placing the samples in a forced ventilation oven at $65{ }^{\circ} \mathrm{C}$ until constant weight was obtained. The roots were weighed on a $0.01 \mathrm{~g}$ precision scale.

An analysis of variance was completed after all data had been collected. The results were compared using the Tukey's test at a significance level of 5\% with the help of Sisvar ${ }^{\circledR}$ software (Ferreira, 2000).

Table 1: Soil chemical and physical properties of dystrophic yellow argisol in the experimental area. Municipality of São Mateus, ES

\begin{tabular}{|c|c|c|c|c|}
\hline \multirow{3}{*}{ Properties } & \multicolumn{4}{|c|}{ Layers } \\
\hline & \multicolumn{2}{|c|}{$0.00-0.20 \mathrm{~m}$} & \multicolumn{2}{|c|}{$0.20-0.40 \mathrm{~m}$} \\
\hline & $\mathbf{R} 1$ & $\mathbf{R 2}$ & $\mathbf{R 1}$ & $\mathbf{R 2}$ \\
\hline \multicolumn{5}{|l|}{ Chemical attributes $^{1 /}$} \\
\hline $\mathrm{pH}\left(\mathrm{H}_{2} \mathrm{O}\right)$ & 5.69 & 5.58 & 5.62 & 5.41 \\
\hline $\mathrm{P}\left(\mathrm{mg} \mathrm{dm}^{-3}\right)$ & 5.09 & 5.52 & 4.35 & 9.45 \\
\hline $\mathrm{K}^{+}\left(\mathrm{mg} \mathrm{dm}^{-3}\right)$ & 30.00 & 35.25 & 26.00 & 36.50 \\
\hline $\mathrm{Ca}^{2+}\left(\mathrm{cmol}_{\mathrm{c}} \mathrm{dm}^{-3}\right)$ & 0.90 & 1.24 & 0.76 & 1.06 \\
\hline $\mathrm{Mg}^{2+}\left(\mathrm{cmol}_{\mathrm{c}} \mathrm{dm}^{-3}\right)$ & 0.40 & 0.47 & 0.31 & 0.43 \\
\hline $\mathrm{Al}^{3+}\left(\mathrm{cmol}_{\mathrm{c}} \mathrm{dm}^{-3}\right)$ & 0.04 & 0.04 & 0.04 & 0.15 \\
\hline $\mathrm{H}+\mathrm{Al}\left(\mathrm{cmol}_{\mathrm{c}} \mathrm{dm}^{-3}\right)$ & 2.78 & 3.26 & 2.74 & 3.55 \\
\hline $\mathrm{SB}\left(\mathrm{cmol}_{\mathrm{c}} \mathrm{dm}^{-3}\right)$ & 1.41 & 1.83 & 1.17 & 1.61 \\
\hline $\mathrm{t}\left(\mathrm{cmol}_{\mathrm{c}} \mathrm{dm}^{-3}\right)$ & 1.44 & 1.87 & 1.21 & 1.76 \\
\hline $\mathrm{T}\left(\mathrm{cmol}_{\mathrm{c}} \mathrm{dm}^{-3}\right)$ & 4.19 & 5.09 & 3.91 & 5.15 \\
\hline $\mathrm{V}(\%)$ & 33.97 & 35.89 & 29.83 & 31.07 \\
\hline $\mathrm{m}(\%)$ & 2.65 & 2.07 & 2.76 & 8.70 \\
\hline $\operatorname{SOM}\left(\mathrm{g} \mathrm{kg}^{-1}\right)$ & 7.71 & 9.56 & 4.94 & 8.21 \\
\hline \multicolumn{5}{|l|}{ Granulometry $^{2 /}$} \\
\hline Sand $\left(\mathrm{g} \mathrm{kg}^{-1}\right)$ & \multicolumn{2}{|c|}{819.41} & \multicolumn{2}{|c|}{774.82} \\
\hline Silt $\left(\mathrm{g} \mathrm{kg}^{-1}\right)$ & \multicolumn{2}{|c|}{37.98} & \multicolumn{2}{|c|}{50.93} \\
\hline Clay $\left(\mathrm{g} \mathrm{kg}^{-1}\right)$ & \multicolumn{2}{|c|}{142.61} & \multicolumn{2}{|c|}{174.25} \\
\hline
\end{tabular}




\section{RESULTS AND DISCUSSION}

As a consequence of a period of intense drought that coincided with the experimental period, all plants were subjected to water deficit conditions, even under R1, the deficit of which was $13.59 \%$ lower than that of R2.

The variables DM, PH, and LA showed a significant interaction between the factors cover crop and irrigation management (Table 2), whereas chlorophyll fluorescence (Table 3) and root growth (Table 4) did not. For the purposes of presenting and discussing results of the cover crop factor in the variables DM, PH, and LA, the species are compared in the $\mathrm{R} 1$ regime (condition of better water supply).

The millets stand out as being superior with respect to the variables DM and $\mathrm{PH}$, although do not differ statistically from the other two species for the variable LA (Table 2). Regarding DM content, BRS 1501 produced approximately $27 \%$ more DM than the other millets, among which there were no significant differences (Table 2). The plants were cut at $52 \mathrm{DAS}$, a period close to the booting stage of millet development, which occurs at approximately 53.5 days after the emergence of the plant, among those millets that are grown for the production of biomass (Costa \& Priesnit, 2014). This is applicable to BRS 1501, which was developed for mass production and adapts well to water deficit conditions. Moreover, it has an average vegetative cycle of 80 to 100 days, which is considered short (Embrapa, 2016). Although all other millets are characterized by good green mass production potential, their growth cycles can be more prolonged compared with that of BRS 1501, with ADR 300 having an early/average cycle of 92 days, ADR 500, a late cycle of 100 days (Embrapa, 2016), and ADRf 6010, a long cycle (Atto Adriana Sementes, 2020). Accordingly, these three important characteristics of the BRS 1501 millet contribute to its higher accumulation of DM compared with that of the other millets, which may explain its better performance under regime $\mathrm{R} 1$.


Cultivation Period (2016)

Figure 1: Values for sunlight, maximum, average, and minimum air temperature (A), rainfall, irrigation, and air relative humidity (B) recorded during the experiment by the automatic network weather station of Inmet, located in the Federal University of Espírito Santo campus in São Mateus. Total rainfall $=153.40 \mathrm{~mm}$.

Rev. Ceres, Viçosa, v. 68, n.4, p. 301-309, jul/aug, 2021 
In previous studies examining the growth of ADR 500, Boer et al. (2007) and Araújo et al. (2015), using seeding densities of $12 \mathrm{~kg} \mathrm{ha}^{-1}$ and $20 \mathrm{~kg} \mathrm{ha}^{-1}$, obtained DM productions of $10,801 \mathrm{~kg} \mathrm{ha}^{-1}$ and $12,710 \mathrm{~kg} \mathrm{ha}^{-1}$, respectively, under conditions of higher precipitation in the Cerrado region of Brazil. Comparatively, in the present study, we obtained an intermediate yield of $12,039 \mathrm{~kg}$ ha ${ }^{1} \mathrm{DM}$ (Table 2), the difference of which may be explicable in terms of the lower water availability, the type of sandy soil, and the intermediate value of seeding density used (16 $\left.\mathrm{kg} \mathrm{ha}^{-1}\right)$. At $52 \mathrm{DAS}$, the RG and JB cover crops still did not realize their maximum potential for DM production, owing to their phenological stages, having only reached the vegetative phase when the millets had already progressed to the pre-flowering stage with a better set. RG is a perennial species (Zanatta et al., 2014) and JB has a growth cycle of 170 to 200 days (Calegari \& Carlos, 2014). In contrast, Adami et al. (2020) has previously observed DM productions of $11,419 \mathrm{~kg} \mathrm{ha}^{-1}$ and $5,400 \mathrm{~kg}$ $\mathrm{ha}^{-1}$ for $B$. ruziziensis and $6,850 \mathrm{~kg} \mathrm{ha}^{-1}$ and 4,342 $\mathrm{kg} \mathrm{ha}^{-1}$ for millet at 94 and 170 days, respectively, thereby highlighting the importance of the effect of phenological stage in the production of DM, as at the time of analysis, millet was already undergoing natural decomposition, whereas B. ruziziensis had reached the stage of full development.

Among the millets, ADR 300, ADR500, and BRS 1501 showed the highest $\mathrm{PH}$, ranging from 1.09 to $1.21 \mathrm{~m}$, whereas ADRf 6010 was the shortest, at $0.87 \mathrm{~m}$ (Table 2). There were no significant differences between the heights of RG and JB, which were characterized by the shortest $\mathrm{PH}$, reaching 0.37 and $0.48 \mathrm{~m}$, respectively (Table 2). Potentially, RG can reach heights of up to $1 \mathrm{~m}$ (Zanatta et al., 2014), whereas the maximum heights of JB and millets (ADR 300, ADR 500, and BRS 1501) can vary from 0.8 to $1.9 \mathrm{~m}$ and 1.5 to $2.5 \mathrm{~m}$, respectively (Calegari \& Carlos, 2014). The ADRf 6010 millet naturally has a smaller size due to its development for use as a forage. Thus, in the present study, the $\mathrm{PH}$ of this millet was below the maximum potential of the species, probably due to the low water availability (Figure 1B) and the low fertility of the soil (Table 1), consequently resulting in lower volumes of biomass. In addition, as discussed for DM, differences in the phenological stages of plants at 58 DAS may have accounted for the observed differences in $\mathrm{PH}$ between species.

We detected no significant differences among the species with respect to LA, which ranged from 2,585 to $3,910 \mathrm{~cm}^{2}$ (Table 2), and can be explained in terms of diversity in the size and number of leaves, with RG, JB, and millets being notable with respect to leaf number, width, and length, respectively, contributing to the comparable LA measurements among plants.

The analysis of variance for chlorophyll fluorescence revealed a significant difference between species for both excitation channels of the Multiplex ${ }^{\circledR}$ device (Table 3 ). JB showed the highest fluorescence index for the adaxial surface of leaves, whereas for the abaxial surface, JB was similar to ADR 300, with the lowest index. However, we detected no significant differences among the other plant types. Chlorophyll contents tend to be higher on the adaxial surface of leaves due to the presence of the chlorophyll-rich palisade parenchyma, the main tissue responsible for photosynthesis in plants, whereas the abaxial surface is comprised primarily of the spongy parenchyma, which is characterized by fewer chloroplasts

Table 2: Dry matter (DM) at 52 DAS, plant height (PH) at 58 DAS and leaf area (LA) at 60 DAS of cover crops cultivated using two irrigation regimes

\begin{tabular}{|c|c|c|c|c|c|c|}
\hline \multirow{2}{*}{ Treat. } & RG & JB & ADR 300 & ADR 500 & ADRf 6010 & BRS 1501 \\
\hline & \multicolumn{6}{|c|}{ DM $\left(\mathrm{kg} \mathrm{ha}^{-1}\right)$} \\
\hline R1 & $5,945 \mathrm{Ca}$ & $5,800 \mathrm{Ca}$ & $12,891 \mathrm{Ba}$ & $12,039 \mathrm{Ba}$ & $12,138 \mathrm{Ba}$ & $17,642 \mathrm{Aa}$ \\
\hline $\mathbf{R} 2$ & $3,077 \mathrm{Bb}$ & $5,248 \mathrm{Ba}$ & $6,863 \mathrm{Bb}$ & $6,528 \mathrm{Bb}$ & $11,409 \mathrm{Aa}$ & $6,876 \mathrm{Bb}$ \\
\hline \multirow[t]{2}{*}{ CV $(\%)$} & Plots & 18.81 & & $\mathrm{CV}(\%)$ & Subplots & 20.79 \\
\hline & \multicolumn{6}{|c|}{ PH (m) } \\
\hline R1 & $0.37 \mathrm{Ca}$ & $0.48 \mathrm{Ca}$ & $1.14 \mathrm{Aa}$ & $1.09 \mathrm{Aa}$ & $0.87 \mathrm{Ba}$ & $1.21 \mathrm{Aa}$ \\
\hline $\mathbf{R 2}$ & $0.23 \mathrm{Cb}$ & $0.47 \mathrm{Ba}$ & $0.78 \mathrm{Ab}$ & $0.66 \mathrm{Ab}$ & $0.79 \mathrm{Aa}$ & $0.71 \mathrm{Ab}$ \\
\hline \multirow[t]{2}{*}{$\mathrm{CV}(\%)$} & Plots & 5.70 & & $\mathrm{CV}(\%)$ & Subplots & 9.91 \\
\hline & \multicolumn{6}{|c|}{$\mathrm{LA}\left(\mathrm{cm}^{2}\right)$} \\
\hline R1 & $3,732 \mathrm{Aa}$ & $3,811 \mathrm{Aa}$ & 3,161 Aa & $3,583 \mathrm{Aa}$ & $3,910 \mathrm{Aa}$ & $2,585 \mathrm{Aa}$ \\
\hline $\mathbf{R} 2$ & $960 \mathrm{Cb}$ & 4,317 $\mathrm{Aa}$ & $2,120 \mathrm{BCa}$ & $1,609 \mathrm{BCb}$ & 2,864 ABa & $1,486 \mathrm{BCa}$ \\
\hline$\overline{\mathrm{CV}}(\%)$ & Plots & 13.58 & & $\mathrm{CV}(\%)$ & Subplots & 30.55 \\
\hline
\end{tabular}

DAS: days after seeding; Treat.: treatments; R1: irrig ation regime 1 (76 mm); R2: irrigation regime 2 (38 mm); RG: ruzi grass; JB: jack bean; CV: coefficient of variation. Averages followed by the same letter do not differ from each other by the Tukey's test at 5\% probability. Uppercase letters correspond to rows, whereas lowercase letters correspond to columns. 
(Taiz \& Zeiger, 2017). In comparison with RG and millet, JB has wider more horizontal leaves, with wide trifoliated cotyledon leaves, and a bright dark green color (Burle et al., 2006), thereby providing greater exposure to solar radiation and enhancing the capacity of the photosynthetic apparatus. Accordingly, the good performance of JB observed in the present study can probably be attributed to its large LA and higher concentration of chloroplasts (adaxial surface), together with the advantages related to its leaf morphology. Differences in photosynthetic attributes, under the conditions examined in the present study, appear to be related only to differences in the families of the studied plants, differentiating the Fabaceae, represented by JB, and the Poaceae, represented by RG and the millets.

In terms of root growth, we detected significant difference between species only for the parameters TRL and ARL. The millets ADR 300, ADR 500, and ADRf 6010 showed the highest values for TRL, whereas ARL values were highest in RG and ADR 300, and JB showed the lowest value for both measures (Table 4). In contrast, we detected no significant differences among plants with respect to TRV, TRSA, ARD, or RDM. These results appear to reflect differences in the root morphologies of the different plant families, with RG and millet (Fabaceae) being differentiated from JB (Poaceae). According to Alcântara \& Bufarah (1999), the root system of plants in the Fabaceae family is comprised predominantly of the main root, which explores soil in a vertical direction, whereas the plants in the family Poaceae are characterized by a larger number of secondary roots, which are distributed both vertically and horizontally. Millet, for example, produces only a seminal root, which lasts for 45 to 60 days and can reach considerable depths under favorable conditions (Embrapa, 2005). Thus, the higher root growth (TRL and ARL) values obtained for millet and $\mathrm{RG}$ are perhaps indicative of their more abundant root system. In turn, a smaller number of secondary roots would be associated with the lower TRL and ARL values that we obtained for JB. A further important factor among plants in the Poaceae, is the length of the life cycle of the plants, with plants having a rapid life cycle, such as millet, being characterized by faster initial root development, compared with plants, such RG, which have a more protracted life cycle.

With regards to the irrigation regime, with the exception of millets ADR 300 and BRS 1501, which did not suffer a significant reduction in the variable LA, all plants showed similar behavior in terms of DM, PH, and LA (Table 2), thereby highlighting the relationship between these variables with respect to plant growth. Therefore, for all assessed variables, RG and ADR 500 were sensitive to water deficiency, whereas JB and ADRf 6010 were tolerant.

Under the $\mathrm{R} 2$ regime, we observed that the cover crops RG, ADR 300, ADR 500, and BRS 1501 suffered significant reductions of approximately $48 \%, 47 \%, 46 \%$, and $61 \%$ in $\mathrm{DM}$ and $38 \%, 32 \%, 39 \%$, and $41 \%$ in $\mathrm{PH}$, respectively. Moreover, RG and ADR 500 suffered significant reductions of approximately $74 \%$ and $55 \%$ in LA, respectively, whereas ADR 300 and BRS 1501 suffered non-significant reductions of approximately $33 \%$ and $42 \%$, respectively. In contrast, we observed JB and ADRf 6010 to be relatively tolerant to a water deficit, showing $10 \%$ and $6 \%$ reductions in DM, $2 \%$ and $9 \%$ reductions in $\mathrm{PH}$, respectively, and an increase of $12 \%$ and reduction of $27 \%$, respectively, in LA.

Owing to differences in water precipitation over the periods evaluated, differences have been reported with respect to reductions in DM in studies that have examined the growth of $P$. americanum and B. brizantha cv. Marandu (Torres et al., 2008) and of P. americanum and B. ruziziensis (Adami et al., 2020). Significant reductions in PH have

Table 3: Chlorophyll $a$ fluorescence index at 60 DAS of cover crops cultivated using two irrigation regimes

\begin{tabular}{|c|c|c|c|c|}
\hline \multirow{2}{*}{ Treat. } & \multicolumn{2}{|c|}{ SFR (G) } & \multicolumn{2}{|c|}{ SFR (R) } \\
\hline & Adaxial & Abaxial & Adaxial & Abaxial \\
\hline $\mathrm{R} 1$ & 1.7317 & 1.3140 & 1.5347 & 1.1930 \\
\hline $\mathrm{R} 2$ & 1.7516 & 1.3543 & 1.5976 & 1.2258 \\
\hline CV (\%) & 2.79 & 4.16 & 6.37 & 3.40 \\
\hline RG & $1.6889 \mathrm{~b}$ & $1.3613 \mathrm{a}$ & $1.6279 \mathrm{~b}$ & $1.2250 \mathrm{a}$ \\
\hline JB & $2.2883 \mathrm{a}$ & $1.1775 \mathrm{~b}$ & $1.9482 \mathrm{a}$ & $1.0779 \mathrm{~b}$ \\
\hline ADR 300 & $1.6399 \mathrm{~b}$ & $1.3121 \mathrm{ab}$ & $1.4608 \mathrm{~b}$ & $1.1934 \mathrm{ab}$ \\
\hline ADR 500 & $1.6236 \mathrm{~b}$ & $1.3537 \mathrm{a}$ & $1.4626 \mathrm{~b}$ & $1.2297 \mathrm{a}$ \\
\hline ADRf 6010 & $1.6204 \mathrm{~b}$ & $1.4206 \mathrm{a}$ & $1.4703 \mathrm{~b}$ & $1.2859 \mathrm{a}$ \\
\hline BRS 1501 & $1.5887 \mathrm{~b}$ & $1.3797 \mathrm{a}$ & $1.4270 \mathrm{~b}$ & $1.2444 \mathrm{a}$ \\
\hline $\mathrm{CV}(\%)$ & 8.88 & 7.52 & 8.77 & 6.46 \\
\hline
\end{tabular}

DAS: days after seeding; SFR: simple fluorescence ratio (channel of excitation: $\mathrm{G}=$ green; $\mathrm{R}=$ red); Treat.: treatments; R1: irrigation regime $1(76 \mathrm{~mm})$; R2: irrigation regime $2(38 \mathrm{~mm})$; RG: ruzi grass; JB: jack bean; CV: coefficient of variation. Averages followed by the same letters, in columns, do not differ from each other by Tukey's test at $5 \%$ probability. 
also been observed under conditions of different water availability for B. ruziziensis and ADR 300 (Petter et al., 2013) and for ADR 300 and BRS 1501 (Santos et al., 2017). Conversely, Bonfim-Silva et al. (2011), using ADR 500, recorded similar heights for this variety at 35 DAS when subjected to water availabilities at $30 \%$ and $60 \%$ of the field capacity.

Although the ADR 300 millet suffered reductions in DM and $\mathrm{PH}$, we detected no statistically significant difference with regards to LA, despite a reduction in absolute value between regimes R1 and R2 (Table 2). Similar results have been obtained by Ramos Junior et al. (2013), who found that the LA of ADR 300 was affected by a reduction in water potential in the soil, ranging from 2,200 to $5,000 \mathrm{~cm}^{2}$. In addition, they found that the variation in PH was similar to that in DM. A reduction of LA is the most prominent response of plants to low water availability and is considered to be a mechanism whereby plants adapt to water deficit (Taiz \& Zeiger, 2017). The results of the present study serve to indicate the prominent effects of water availability on DM, $\mathrm{PH}$, and LA.

We anticipated that the difference in water stress between $\mathrm{R} 1$ and $\mathrm{R} 2$ would be reflected in our physiological measurements of chlorophyll fluorescence (Table 3), particularly in RG and ADR 500, which were characterized by significant reduction in LA in response to water deprivation (Table 2). However, physiologically, the plants showed a comparable pattern of behavior, indicating a similarity in their responses to the two irrigation regimes and, consequently, maintenance of the photosynthetic potential, given that this potential is directly related to the chlorophyll content of leaves. Accordingly, this implies that the rate of photosynthesis is not more sensitive than leaf area to water stress, as pointed out by Taiz \& Zeiger (2017). Petter et al. (2013) found that the chlorophyll content of $B$. ruziziensis was significantly influenced by water deficiency, which was not observed for ADR 300 millet, whereas, Bonfim-Silva et al. (2011) detected no significant differences among corn, sorghum, and millet (Poaceae), with respect to chlorophyll content, although they did record differences in the response to different water availabilities. As shown in Table 3, RG and millet showed no significant differences with respect chlorophyll, consistent with the findings of the aforementioned study by Bonfim-Silva et al (2011). Contrastingly, however, the irrigation regime did not appear to influence these results. It could, thus, be inferred that the difference in water restriction between R1 and R2 was small to promote difference in the physiological response. Assessments of chlorophyll fluorescence using the Multiplex ${ }^{\circledR}$ (Agati et al., 2012; Longchamps \& Khosla, 2014) can be useful for detecting abiotic water stress over intervals of water deficiency longer than that imposed in the present study.

We also found that the irrigation regime did not significantly influence the root parameters assessed in the present study, which contrasts with the findings reported by Petter et al. (2013), who observed reductions in root dry matter and root volume in response to an increased water deficit in ADR 300 and B. ruziziensis. Similarly, Ramos Junior et al. (2013) observed a reduction in the root dry matter in ADR 300 in response to a reduction in water availability; however, the length of time that plants were exposed water deficiency was notably longer than that imposed in the present study.

During our analysis of the roots of cover plants, we observed that plants in the Poaceae were characterized by roots with a higher total volume and smaller individual thickness, whereas in contrast, the roots of JB had a lower total volume but greater individual thickness. These

Table 4: Total root length (TRL), average root length (ARL), total root volume (TRV), total root surface area (TRSA), average root diameter (ARD) and root dry matter (RDM) at 65 DAS of cover crops cultivated using two irrigation regimes

\begin{tabular}{lcccccc}
\hline Treat. & TRL $(\mathbf{m m})$ & ARL $(\mathbf{m m})$ & TRV $\left(\mathbf{m m}^{\mathbf{3}}\right)$ & TRSA $\left(\mathbf{m m}^{\mathbf{2}}\right)$ & ARD $(\mathbf{m m})$ & RDM $(\mathbf{g})$ \\
\hline R1 & $3,898.99$ & 14.44 & $1,907.27$ & $6,632.88$ & 0.4695 & 1.3686 \\
R2 & $2,653.61$ & 12.76 & $1,704.16$ & $5,643.96$ & 0.4053 & 1.3628 \\
\hline CV $(\%)$ & 49.84 & 59.82 & 181.80 & 110.16 & 66.52 & 1.87 \\
\hline RG & $2,900.45 \mathrm{ab}$ & $15.79 \mathrm{a}$ & $1,626.82$ & $5,769.66$ & 0.4908 & 1.3703 \\
JB & $1,155.62 \mathrm{~b}$ & $9.20 \mathrm{~b}$ & 490.43 & $1,972.09$ & 0.4202 & 1.3690 \\
ADR 300 & $4,488.66 \mathrm{a}$ & $15.18 \mathrm{a}$ & $2,893.21$ & $8,810.65$ & 0.4589 & 1.4104 \\
ADR 500 & $4,230.94 \mathrm{a}$ & $14.82 \mathrm{ab}$ & $2,585.08$ & $8,458.02$ & 0.4443 & 1.3240 \\
ADRf 6010 & $4,042.80 \mathrm{a}$ & $14.74 \mathrm{ab}$ & $2,225.04$ & $7,320.99$ & 0.4072 & 1.3459 \\
BRS 1501 & $2,839.34 \mathrm{ab}$ & $11.88 \mathrm{ab}$ & $1,013.70$ & $4,500.10$ & 0.4030 & 1.3746 \\
\hline CV $(\%)$ & 50.61 & 28.70 & 131.04 & 78.01 & 33.88 & 5.42
\end{tabular}

DAS: days after seeding; Treat.: treatments; R1: irrigation regime 1 (76 mm); R2: irrigation regime 2 (38 mm); RG: ruzi grass; JB: jack bean; CV: coefficient of variation. Averages followed by the same letters, in columns, do not differ from each other by Tukey's test at $5 \%$ probability. 
contrasting traits may explain why we detected no significant differences in our assessments of the other root variables TRL, TRSA, ARL, and RDM assessments. Moreover, although overall, JB had a smaller root volume, in terms of weight, the roots of this plant showed values intermediate among those of the other plants, thereby indicating a trade-off between these traits among plants in the families Poaceae and Fabaceae.

Given the relatively small volumes of the root samples collected in the present study, which can be attributed to the operational limitations associated with our root evaluations, we suspect that the quantitative indices obtained suggest a trend regarding the behavior of this variable, rather than indicating a definitive response. More substantial changes in the root system would be expected to occur in response a larger difference in water deficit.

On the basis of our analyses of all variables under the $\mathrm{R} 2$ regime, in general, the millets, particularly ADRf 6010, show better adaptability to water deprivation, followed by JB and, finally, RG. Millet, according to Wutke et al. (2014), is a plant adapted to soils of different textures and low fertility, with high resistance to drought. In addition, ADRf 6010 is a hybrid millet, and therefore has genetic superiority, expressing better characteristics, such as better adaptability, production, and performance, when compared with its parents, which may have accounted for its better performance compared with the other millets assessed. JB is characterized by a relatively deeppenetrating root system, which thereby confers drought tolerance, and is adapted to practically all types of soil. Moreover, it has the ability to fix atmospheric N, thereby enhancing nutrient absorption efficiency (Mascarenhas \& Wutke, 2014). With regards to RG, we suspect that a combination of water deficiency, a short assessment time, and low soil fertility in the experimental area (Table 1) may all have contributed to compromising its performance. Further studies designed to include longer periods of assessment for the factors of interest will contribute to gaining a better understand the performance of these species in the Coastal Tablelands region.

\section{CONCLUSIONS}

In this study, we found that the irrigation regime imposed influences the agronomic performance of most of the cover crops we assessed, with the exceptions being jack bean and the ADRf 6010 millet, which were tolerant to water deficiency, based on our evaluations of the variables shoot dry matter, plant height, and leaf area.

In terms of biomass production, ADRf 6010 millet is the most suitable crop for use in conservation systems under conditions of water stress in the Coastal Tablelands region.

\section{ACKNOWLEDGMENTS, FINANCIAL SUPPORT AND FULL DISCLOSUSE}

The Fundação de Amparo à Pesquisa e Inovação do Espírito Santo (FAPES) for financial support and the Coordenação de Aperfeiçoamento de Pessoal de Nível Superior (CAPES) for granting a scholarship.

The authors have no conflict of interest in the conduct of the research and in the publication of the manuscript.

\section{REFERENCES}

Adami PF, Colet RA, Lemes ES, Oligini KF \& Batista VV (2020) Plantas de cobertura nas entressafras soja-trigo e soja-soja. Brazilian Journal of Development, 06:16551-16567.

Agati G, Foschi L, Grossi N, Guglielminetti L, Cerovic ZG \& Volterrani M (2012) Fluorescence-based versus reflectance proximal sensing of nitrogen content in Paspalum vaginatum and Zoysia matrella turfgrass. European Journal of Agronomy, 45:39-51.

Alcântara PB \& Bufarah G (1999) Plantas forrageiras: gramíneas e leguminosas. São Paulo, Nobel. 163p.

Alvares CA, Stape JL, Sentelhas PC, Gonçalves JLM \& Sparovek G (2013) Koppen's climate classification map for Brazil. Meteorologische Zeitschrift, 22:711-728.

Araújo LS, Cunha PCR, Silveira PM, Sousa Netto M \& Oliveira FC (2015) Potencial de cobertura do solo e supressão de tiririca (Cyperus rotundus) por resíduos culturais de plantas de cobertura. Revista Ceres, 62:483-488.

Atto Adriana Sementes (2020) Milheto ADRf 6010. Available at: http://www.attosementes.com.br/adrf-6010-valente/. Accessed on: June $15^{\text {th }}, 2020$.

Boer CA, Assis RL, Silva GP, Braz AJBP, Barroso ALL, Cargnelutti Filho A \& Pires FR (2007) Ciclagem de nutrientes por plantas de cobertura na entressafra em um solo de Cerrado. Pesquisa Agropecuária Brasileira, 42:1269-1276.

Bonfim-Silva EM, Silva TJA, Cabral CEA, Kroth BE \& Rezende D (2011) Desenvolvimento inicial de gramíneas submetidas ao estresse hídrico. Revista Caatinga, 24:180-186.

Burle ML, Carvalho AM, Amabile RF \& Pereira J (2006) Caracterização das espécies de adubo verde. In: Carvalho AM \& Amabile RF (Eds.) Cerrado: Adubação Verde. Planaltina, Empresa Brasileira de Pesquisa Agropecuária. p.71-142.

Calegari A \& Carlos JAD (2014) Recomendações de plantio e informações gerais sobre o uso de espécies para adubação verde no Brasil. In: Lima Filho OF, Ambrosano EJ, Rossi F \& Carlos JAD (Eds.) Adubação Verde e Plantas de cobertura no Brasil: Fundamentos e Prática. Brasília, Empresa Brasileira de Pesquisa Agropecuária. p.453-478.

Costa ACT \& Priesnitz R (2014) Influência do arranjo espacial do milheto em relação aos estádios fenológicos e unidades térmicas. Global Science and Technology, 07:37-47.

Day PR (1965) Particle fractionation and particle-size analysis. In: Black CA (Ed.) Methods of soil analysis. Madison, American Society of Agronomy. p.545-566.

Empresa Brasileira de Pesquisa Agropecuária (1997) Manual de métodos de análise de solo. $2^{\text {nd }}$ ed. Rio de Janeiro, Centro Nacional de Pesquisa de Solo. 212p.

Empresa Brasileira de Pesquisa Agropecuária - Embrapa Milho e Sorgo (2005) Milheto: tecnologias de produção e agronegócio. Brasília, Embrapa Informação Tecnológica. 216p. 
Empresa Brasileira de Pesquisa Agropecuária - Embrapa Milho e Sorgo (2016) Cultivo do Milheto. Available at: https:// www.spo.cnptia.embrapa.br/conteudo?p_p_id=conteudoportlet_WAR_sistemasdeproducaolf6_1ga1ceportlet\&p_p_lifecycle $=0 \& p \_p \_s t a t e=$ normal\&p_p_mode $=$ view $\& p \_p \_c o l \_i d=c o-$ lumn-2\&p_p_col_count=1\&p_r_p_-76293187_sistemaProducaoId=8101\&p_r_p_-996514994_topicoId=9018. Accessed on: June $15^{\text {th }} .2020$.

Ferreira DF (2000) Análise estatística por meio do SISVAR (Sistema para Análise de Variância) para Windows versão 4.0. In: 45 Reunião Anual da Região Brasileira da Sociedade Internacional de Biometria, São Carlos. Proceedings, UFSCar. p.255-258.

Gama-Rodrigues AC, Gama-Rodrigues EF \& Brito EC (2007) Decomposição e liberação de nutrientes de resíduos culturais de plantas de cobertura em Argissolo Vermelho-Amarelo na região noroeste fluminense-RJ. Revista Brasileira de Ciência do Solo, 31:1421-1428

Instituto Nacional de Meteorologia - Inmet (2016) Estação Automática de São Mateus (ES). Available at: http:// www.inmet.gov.br/sonabra/pg_dspDados Codigo_sim.php?QTYxNg==. Accessed on: October 18 ${ }^{\text {th }}, 2016$.

Jorge LAC \& Rodrigues AFO (2008) Safira: sistema de análise de fibras e raízes. São Carlos, Embrapa Instrumentação Agropecuária. 21p. (Technical Bulletin, 24).

Longchamps L \& Khosla R (2014) Early detection of nitrogen variability in maize using fluorescence. Soil Fertility \& Crop Nutrition, 106:511-518.

Marcante NC, Camacho MA \& Paredes FPJ (2011) Teores de nutrientes no milheto como cobertura de solo. Bioscience Journal, 27:196-204.

Mascarenhas HAA \& Wutke EB (2014) Adubação, nutrição e fatores climáticos limitantes ao desenvolvimento dos adubos verdes. In: Lima Filho OF, Ambrosano EJ, Rossi F \& Carlos JAD (Eds.) Adubação Verde e Plantas de cobertura no Brasil: Fundamentos e Prática. Brasília, Empresa Brasileira de Pesquisa Agropecuária. p.191-224.

Pedrotti A, Silva TO, Araújo EM, Araújo Filho RN \& Holanda FSR (2015) Atributos químicos do solo modificados por diferentes sistemas de cultivo associados a culturas antecessoras ao cultivo do milho, nos Tabuleiros Costeiros. Magistra, 27:292-305.
Petter FA, Pacheco LP, Zuffo AM, Piauilino AC, Xavier ZF, Santos JM \& Miranda JMS (2013) Desempenho de plantas de cobertura submetidas à déficit hídrico. Semina: Ciências Agrárias, 34:3307-3320.

Quaggio JA (1983) Critérios para calagem em solos no estado de São Paulo. Master Dissertation. Escola Superior de Agricultura Luiz de Queiroz, Universidade de São Paulo, Piracicaba. 76p.

Ramos Junior EU, Machado RAF, Olibone D, Castoldi G \& Ramos BM (2013) Crescimento de plantas de cobertura sob déficit hídrico. Semina: Ciências Agrárias, 34:47-56.

Santos HG, Jacomine PKT, Anjos LHC, Oliveira VA, Lumbreras JF, Coelho MR, Almeida JA, Cunha TJF \& Oliveira JB (2013) Sistema brasileiro de classificação de solos. $3^{\text {rd }}$ ed. Brasília, Embrapa. 353p.

Santos R, Neves AL, Pereira LG, Verneque R, Costa CT, Tabosa J, Scherer C \& Gonçalves L (2017) Divergence in agronomic traits and performance of pearl millet cultivars in Brazilian semiarid region. Grassland Science, 63:118-127.

Silva MP, Arf O, Sá ME, Abrantes FL, Berti CLF \& Souza LCD (2017) Plantas de cobertura e qualidade química e física de Latossolo Vermelho distrófico sob plantio direto. Revista Brasileira de Ciências Agrárias, 12:60-67.

Taiz L, Zeiger E, Moller IM \& Murphy A (2017) Fisiologia e desenvolvimento vegetal. $6^{\text {th }}$ ed. Porto Alegre, Artmed. 858p.

Torres JLR, Pereira MG \& Fabian AJ (2008) Produção de fitomassa por plantas de cobertura e mineralização de seus resíduos em plantio direto. Pesquisa Agropecuária Brasileira, 43:421-428.

Wutke EB, Calegari A \& Wildner LP (2014) Espécies de adubos verdes e plantas de cobertura e recomendações para seu uso. In: Lima Filho OF, Ambrosano EJ, Rossi F \& Carlos JAD (Eds.) Adubação Verde e Plantas de cobertura no Brasil: Fundamentos e Prática. Brasília, Empresa Brasileira de Pesquisa Agropecuária. p.61-167.

Wutke EB, Trani PE, Ambrosano EJ \& Drugowich MI (2009) Adubação verde no Estado de São Paulo. Campinas, CATI. 89p.

Zanatta JA, Salton JC \& Ceccon G (2014) Sistemas de integração lavoura-pecuária como estratégia para melhorar a fertilidade do solo. In: Lima Filho OF, Ambrosano EJ, Rossi F \& Carlos JAD (Eds.) Adubação Verde e Plantas de cobertura no Brasil: Fundamentos e Prática. Brasília, Empresa Brasileira de Pesquisa Agropecuária. p.375-416. 